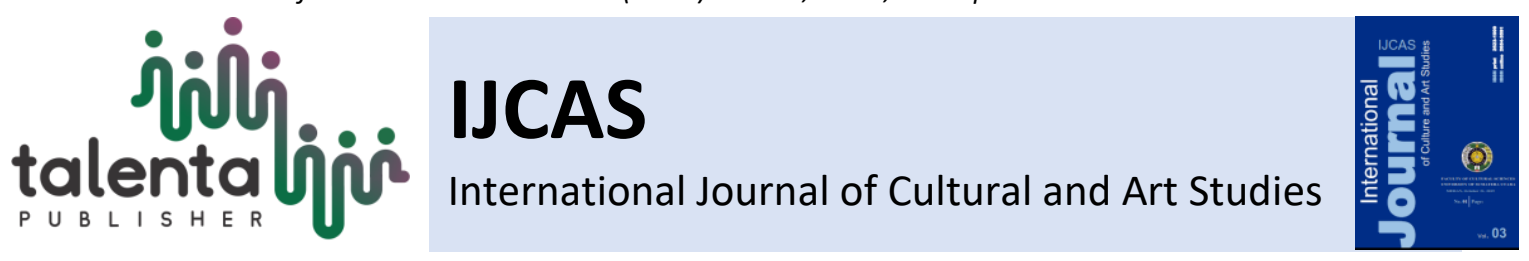

\title{
Illocutionary Acts in President Rodrigo Duterte's Speech.
}

\author{
Muhammad Kiki Wardana ${ }^{1 *}$, Sumita Roy ${ }^{2}$, Juan Ariska ${ }^{3}$ \\ ${ }^{1,3}$ Faculty of Communication and Languages, University of Harapan Medan, Indonesia \\ 3,2 Osmania University, Hyderabad, India
}

\begin{abstract}
This research attempts to figure out the speech act of President of The Republic of The Philippines, Rodrigo Duterte, particularly in identifying types of the Illocutionary act and perlocutionary act in SONA Forum. The researcher is keen to explore Duterte's speech because Duterte is notorious for his unfavorable remarks. Therefore, by investigating his speech through the analysis of his speech act in the selected speech, the researcher will prove whether the speech contains the perlocutionary acts of insulting or not. This research also focuses on utilizing Searle's theory on Illocutionary acts exemplifies 5 different types of illocutionary acts namely Assertive which is divided into stating, suggesting, boasting, complaining and claiming. Another type is Directives, which comprises of ordering, commanding, requesting, advising and recommending. Expressive type comprises thanking, congratulating, pardoning, blaming, praising, and condoling. Commisive type includes promising, vowing, and offering. The last type is Declaration. The researchers use descriptive qualitative method by doing transcription of the speech and meticulously analyze every word.
\end{abstract}

Keywords: Pragmatic, Speech act, John Searle's Theory, Perlocutionary act, Illocutionary act.

Received 22 October 2019 | Revised 30 October 2019| Accepted 31 October 2019

\section{Introduction}

In general, language is utilized to bring meaning and tools of social communication. However, to comprehend meaning sometimes is not as easy as imagined. It needs a series of appropriate comprehension in understanding the intended meaning. The failure to locate the right meaning can obviously lead into misunderstanding and create incorrect implicature. In order to possess a clear-cut meaning, the speaker is advised to apply some strategies in conveying the message. Therefore, by understanding the system of meaning in semantics and pragmatics is considered paramount. Language strategy has a very important role in the communication process, and pragmatics offers a guideline for both speaker and listener to attain the goal of communication: being well understood.

\footnotetext{
* Corresponding author at: Faculty of Communication and Languages, University of Harapan Medan, Indonesia.
} 


\section{Theoretical Framework}

\subsection{Pragmatic}

Pragmatics is the study which belief is what is communicated is more than what is said. [1, p. 3] It has consequently more to do with the analysis of what people mean by their utterance that what the words or phrase in those utterance might mean by themselves. To understand speaker's meaning, we might also pay attention to the context .Thus, pragmatics also concern with concern. More clearly, Yule [1] continues that pragmatics should also consider aspects pf context such as who people are talking to, when, where, and under what circumstances that will determine the way they say and what they want to say.

\subsection{Speech act}

According to Searle [2, p. 17-18], the speech act or acts performed in the utterance of a sentences are in general a function of the meaning of the sentence.

Searle in Rahardi [3, p. 35-36] in the Searle's book, Speech act an essay in the philoshopy of language, stating that in practice the use of language there are at least three kinds of speech acts. These are three kinds of speech acts that now can be describe as follows locutionary acts, illocutionary acts, and perlocutionary acts.

* Locutionary acts are a speech with words, phrases, and sentences, according to the meaning contained by words, phrases, and sentences that. This speech act may be cited as the act of saying something. In a locutionary acts are not question the purpose and function of the speech delivered by the speaker, so the speech of my hand its for example, solely intended to inform the partner said that at the time at hand speaker said that the speech is in a state of itching.

* Illocutionary act is an act of doing something with a purpose and a specific function anyway. Speech act can be considered as the act of doing something. Speech my hand itch spoken speakers is solely intended to inform the partners said that said the speech was itching was lodged in the hands of the speaker but the speaker want hearer to perform certain action associated with itching on his hands.

* Perlocutionary act is a follow-growing influence (effect) to the hearer. This speech act can be used to regenerate the effect (effect) the fear of the hearer. Fear arises, for example because the speech said it works as a bouncer who in their daily activities very closely with hitting and injuring others

Furthermore, Searle in Rahardi [3, p. 35-36], classifies the communication function in illocutionary act divided into five kinds. The fifth form of speech that shows the function that can be summarized as follow: 
Assertive, the form said that binds speakers at the truth of a proposition disclosed, such as :

a. Stating is someone says or writes officially or an action done to express an opinion, for example: I have aim, it is for your safety

$b$. Suggesting is to mention an idea, possible plan or action for other people to consider, for example: I think you made a wrong decision

c. Boasting is to speak too proudly or happily about what you have done or what you own, for example: And I don't know if I am going to be boasting now, but in 2006 alone, we won three international awards

$d$. Complaining is to say that something is wrong or not satisfactory, for example: your service is not good

$e$. Claiming is to say that something is true or is fact, although you cannot prove it and other people might not believe it, for example : Jobs will be created by the new program

* Directives, namely the form of speech intended speakers to create the effect thet the hearer take action, such as:

a. Ordering is a request to make, supply or deliver food or goods, for example : I order you to report to the manager

$b$. Commanding is having the authority to give order, for example: our team was in a commanding position as the game neared its end

$c$. Requesting is the act of politely or officially asking for something, for example: please lend me your shoes

$d$. Advising is to give someone advice, for example: my advice is to sell your old car and get a new one

$e$. Recommending is to suggest that someone or something would be good or suitable for a particular job or purpose or to suggest that a particular action should be done, for example: to the sick the doctors wisely recommend a change of air and scenery

* Expressive is a form of speech that serves to express or show the psychological attitudes of speakers towards a situation. Such as:

a. Thanking is to express to someone that you are pleased about or are grateful for something that they have done, for example: I should really be thanking you sir for leading my team

$b$. Congratulating is to praise someone and say that you approve of or are pleased about a special or unusual achievement, for example: congratulating on the winner of your competition 
c. Pardoning is to forgive someone for something they have said or done, for example: pardon sir, could you explain again?

$d$. Blaming is to say or think that someone or something did something wrong or is responsible for something bad happening, for example: my father always blames me everything on me

$e$. Praising is to express admiration or approval of the achievement or characteristic of a person or thing, for example: your face is beautiful

$f$. Condoling is to express sympathy with a person who is suffering sorrow, misfortune, or grief. For example: I am sorry for the death of your parents

* Commisive, namely, the nature of speech serves to express promise or offer. Such as:

a. Promising is something that is promising show sign that it is going to be successful or enjoyable, for example: I promise to love you for the rest of my life

$b$. Vowing is to make a determined decision or promise to do something, for example: she hurried from the forest, vowing she would never go back

c. Offering is something that you give or offer to someone, for example: to be fair, his father had not made things any better by offering money to Jim and not his brother

* Declaration is the form of speech utterances linking content with the fact. Such as:

a. Resigning is to give up a job or position by telling your employer that you are leaving, for example: shall we forever resign the pleasure of construction to the carpenter

$b$. Dismissing is to decide that something or someone is not important and not worth considering, for example: he wanted desperately to dismiss she from consideration

c. Christening is a Christian ceremony at which a baby is given a name and made a member of the Christian church, for example: it was a supper to celebrate the christening of their baby

$d$. Appointing is to choose someone officially for a job or responsibility, for example: after his parents died, the boy's uncle was appointed as his guardian

$e$. Naming is the activity of saying publicly that a person, company, etc. has behaved in a bad or illegal way, for example: she had already declared her intention of naming the baby jasmine whether it was a boy or girl

$f$. Excommunicating is when the Christian church, especially the roman catholic church, excommunicates someone, it refuse to give that person communion and does not allow them to be involved in the church, for example: he was excommunicated 
g. Sentencing is a group of words, usually containing a verb, that express a thought in the form of statement, question, instruction, or exclamation and starts with a capital letter when written, for example: I sentence you to ten years in prison convey the idea. Speech is the ability to speak in front of the public to express their opinion or give an idea about something important.

Speech act is a kind of verbal communication. The word speech acts are derived from two words they are Speech and Act. Speech is the utterance that occurs and act means action.

Furthermore, Searle in: classified the illocutionary speech act in five kinds of utterance each have a communicative function. The fifth forms of speech that showed the from function that can be summarized as follows assertive, directives, expressive, commissive, declaration.

The writer choses to analyze the speech act theory introduced Searle in Rahardi [3]. Based on the explanation above in this research. the writer would analyze what is the most dominant sentence in illocutionary act and what are process of illocutionary in the speech done by President Rodrigo Duterte at SONA, Quezon City,23 July 2018. The writer could find what is dominant sentence of illocutionary act in the speech of President Rodrigo Duterte at SONA, Quezon city and the writer found what are process illocutionary act by President Rodrigo Duterte by using Searle's speech act theory. The reason the writer took the President Rodrigo Duterte as an object of the research because he is famous, according to sources from the news www.suara.com mentions that President Rodrigo Duterte was named the most influential figure in the world in 2017. Many of his speeches made controversies, one of which was his speech at the SONA event, Quezon City who said that he would punish every person who was proven to use drugs. In one of his speeches, he also said that God was stupid. That is why the writer was interested in researching the content of the speech he delivered.

\section{Findings}

The data in this finding section were the assertive of outstanding data, which found after reading speech transcript. Then watching the video. The writer presented the finding of speech act kinds according to Jhon Searle theory. Especially classified the process of illocutionary acts. The writer also presented the most dominant sentence of the illocutionary act in diagram table.

The result of this study showed the writer just found 4 kinds of illocutionary acts, there were: 86 Assertive, 57 Directives, 18 Expressive, 21 commissive, and 0 declaration As the result of analyzing the illocutionary act that is found in Rodrigo Duterte speech, we can the dominant illocutionary act used inn Rodrigo Duterte speech used Nawawi's formula [4] 
$\mathrm{X}=\mathrm{Y} / \mathrm{Nx} 100 \%$

$\mathrm{X}=$ the percentage of illocutionary act in the speech

$\mathrm{Y}=$ the number of illocutionary act that had been analyzed

$\mathrm{N}=$ the total of illocutionary act that had been found

Tabel 1. Result of illocutionary act

\begin{tabular}{|c|c|c|c|c|}
\hline No & Illocutionary act & Number of illocutionary act & Formula & Percentage \\
\hline 1 & Assertive & 86 & $86 / 182 \times 100 \%$ & $47,25 \%$ \\
\hline 2 & Directive & 57 & $57 / 182 \times 100 \%$ & $31,31 \%$ \\
\hline 3 & Expressive & 18 & $18 / 182 \times 100 \%$ & $9,89 \%$ \\
\hline 4 & Commissive & 21 & $21 / 182 \times 100 \%$ & $11,53 \%$ \\
\hline 5 & Declaration & 0 & 0 & 0 \\
\hline & Total & 181 & & $100 \%$ \\
\hline
\end{tabular}

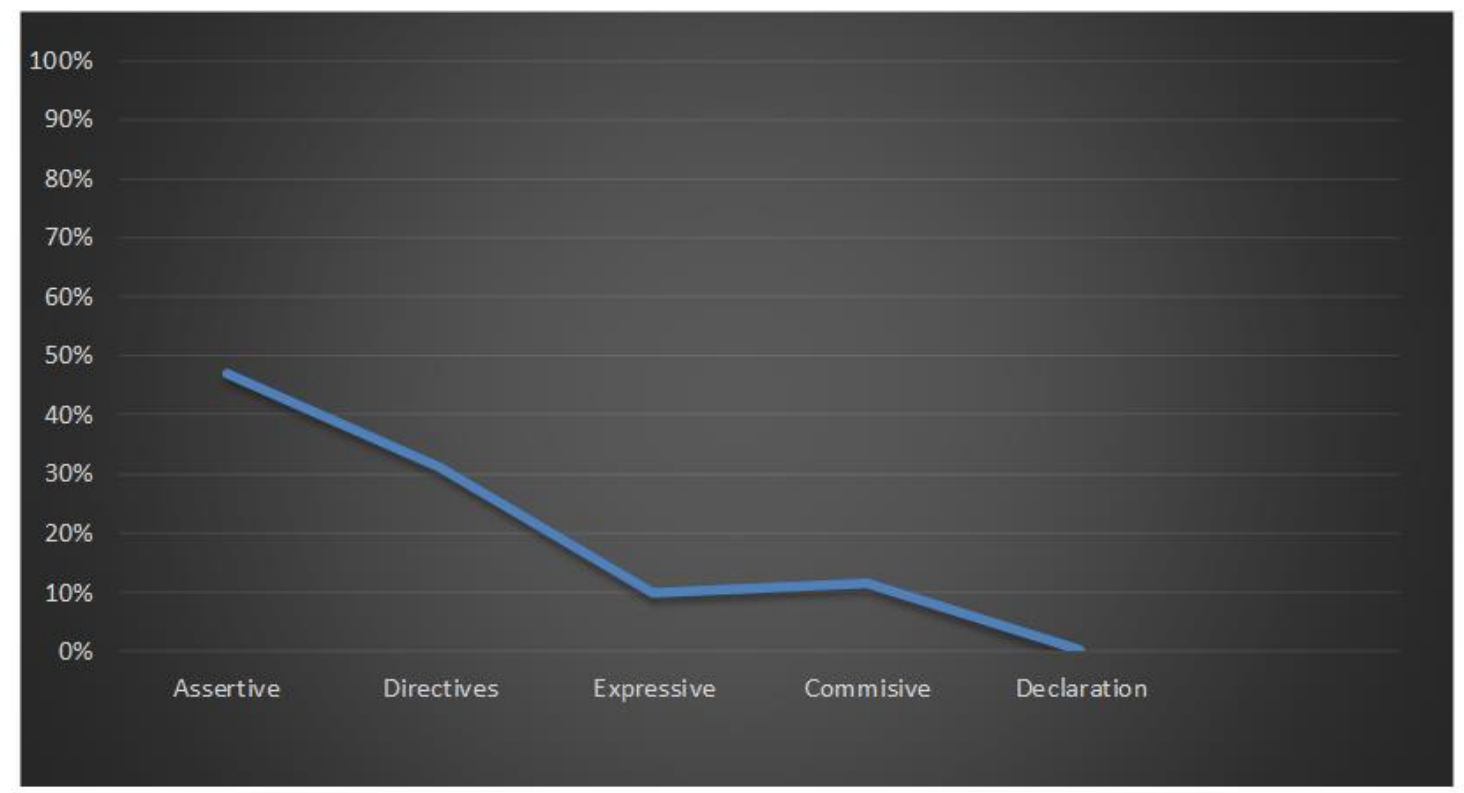

Figure 1. Illocutionary Act Diagram (Nawawis's Formula)

The dominant sentence of illocutionary act in the speech of president Rodrigo Duterte in SONA, Quezon City, July 28, 2018 is Assertive sentence 47,25\%, included stating 71, suggesting 9, boasting 0 , complaining 3 , claiming 3 .

Directives sentence $31,31 \%$, include ordering 7 , commanding 15 , requesting 18 , advising 16 , recommending 1.

Expressive sentence 9,89\%, include thanking 6, congratulating 0, pardoning 1, blaming 2, praising 9 , condoling 0 . 
Commissive sentence $11,53 \%$, include promising 15, vowing 3, offering 3 .

Declaration sentence $0 \%$, include resigning 0 , dismissing 0 , christening 0 , appointing 0 , naming 0 , excommunicating 0 , sentencing 0 .

\section{Conclusions}

After analyzing the data, it is important to conclude what is elaborated before. So,the conclusion of the research is:

Based on the problem of the study in this research, the writer just focused on analyzing the process of illocutionary act and the dominant sentence in the speech of President Rodrigo Duterte. As the first of problem of the study in this research; how are the process of illocutionary act used by President Rodrigo Duterte? Then the writer found types of the process of illocutionary act, they were 86 assertive, 57 directives, 18 expressive, 21 commissive, 0 declaration (the writer did not find any declaration in speech of president Rodrigo Duterte). As the second of problem statement in this research: what is the most dominant sentence of illocutionary act in the speech of president Rodrigo Duterte? Then, the most dominant sentence of illocutionary act in the speech is Assertive sentence included 71 stating, 9 suggesting, 0 boasting, 3 complaining, 3 claiming. Based on the explanation above, the writer conclude that the illocutionary act in this speech by president Rodrigo Duterte in SONA, Quezon City July 28, 2018.

\section{REFERENCES}

[1] G. Yule, "Pragmatics". Oxford University Press. 1996.

[2] J. R. Searle, "Introduction to the Theory of Speech Acts".Cambridge University Press. 1985.

[3] K. Rahardi, "PRAGMATIC Kesatuan Imperativf Bahasa Indonesia". Jakarta: Penerbit Erlangga. 2005.

[4] H. Nawawi, "MetodePenelitianKualitatif" Bandung: RemajaRosdakarya. 1991.

[5] J.R. Searle, "SPEECH ACT An essay in the philoshopy of Language".Cambridge

[6] "Full Speech by President Rodrigo Duterte at SONA,Quezon City,23 july 2018,Taken from SONA 2018 Duterte Speech(Full) July 23rd, 2018https://youtu.be/rjT8PVF2AE1

[7] A. M. Mukti. "Pembinaan kemampuan Berbicara Bahasa Indonesia". Jakarta: Erlangga. 1998

[8] J.L. Austin, "How to Do Things with Words". Oxford: Oxford University Press. 1962

[9] R. Choerunissa, "An Analysis of Speech Act in the Dead Poets Society". A thesis: Universitas Negeri Yogyakarta. 2015.

[10] W. A. C. Dewi,"Speech act in the Great Gatsby Movie Script". A thesis : IAIN Tulungagung. 2014.

[11] A. Dinu, , Pragmatics 1.February,2012 https:/docplayer.net>21465270-pragmatics University Press:United Kingdom. 1969.

[12] Sugiyono. "Metode Penelitian Administrasi".Bandung:Alfabeta. 2005.

[13] W K. Charles. "Introduction English Semantic". London: Routledge.1998. 